\title{
Chronic Fatigue Syndrome Among Teachers in the Conditions of Distance Learning
}

\author{
Marina Anatolyevna Kruglova ${ }^{1, *}$, Elena Stanislavovna Starchenkova ${ }^{1}$, Vladimir \\ Georgievich Kruglov ${ }^{1}$, Natalia Evgenievna Vodopyanova ${ }^{1}$, Oleg Valentinovich \\ Leontiev $^{2}$ and Vladimir Anatolyevich Kruglov ${ }^{2}$
}

\author{
${ }^{1}$ Saint Petersburg State University, Saint Petersburg, 199034, Russia \\ ${ }^{2}$ University at IPA EurAsEs, St. Petersburg, 194044, Russia \\ * Corresponding author e-mail: marakruglova@mail.ru
}

\begin{abstract}
The features of professional pedagogical activity increase the likelihood of teachers' health decline. However, having the resources to cope with difficulties can mitigate the tension caused by occupational stress. In recent years, many authors have noted that chronic fatigue syndrome is a multi-causal pathology and many factors affect its development, one of which is high stress load. The stress load includes both the strengthening of the requirements for the professional activity of the teacher, and the complication of the external situation, an increase in the level of its uncertainty due to the pandemic of COVID-19 and self-isolation. This article considers the issues of professional health of teachers and the risk of developing chronic fatigue syndrome in the process of introducing new educational technologies during a pandemic. The study was conducted in two stages: shortly before the introduction of distance learning in general education schools in connection with the transition to self-isolation due to the COVID-19 pandemic and after the introduction of distance learning. The presence of chronic fatigue syndrome was determined using The Fatigue Assessment Scale (FAS) (H. J.

Michielsen, adapted by L. F. Bikbulatova) and the questionnaire "Criteria for chronic fatigue syndrome" (S. G. Komarov). Methods of mathematical statistics: The Pearson's chi-squared test and the Mann-Whitney U test. Statistical data processing was carried out using the SPSS-20.0 program. It has been established that the introduction of a distance learning format in general education schools is a stressful factor for teachers. After the introduction of the distance learning format, a significant part of the teachers was found to have pathological fatigue, as well as a high risk of developing chronic fatigue syndrome.
\end{abstract}

Keywords: chronic fatigue syndrome, teachers, distance education, health

\section{INTRODUCTION}

The continuous development of technology, the increase in the pace of life and the flow of information that needs to be processed, make serious demands on a teacher in the modern world. These requirements create a situation of increased responsibility. The growing load on an educator can lead to stress, disruptions in the functioning of the body and the formation of new "diseases of civilization", one of which is chronic fatigue syndrome.

The conditions of the pandemic of COVID-19 in 2020 forced educators to rely on distance learning. This led to an additional increase in the requirements for specialists in the educational sphere and contributed to the growth of their psychological stress due to the need to master new formats of interaction with students in a short time.

The situation of uncertainty, due to a possible second wave of the pandemic, aggravates the stressful load on a person, weakening his (or her) immunity. This can serve as a trigger for the development of chronic fatigue syndrome. The relative novelty of the syndrome does not provide a clear idea of the causes, mechanisms of origin, and development of that disease. The consequence of this is the lack of a universal treatment algorithm. At the same time, chronic fatigue syndrome can be the cause of an individual's vulnerability to COVID-19. In this regard, it is necessary to develop a system of prevention of chronic fatigue syndrome, based on the identification of its predictors.

\section{CHRONIC FATIGUE SYNDROME, PROFESSIONAL ACTIVITY AND HEALTH OF THE TEACHER}

\subsection{Chronic fatigue syndrome}

Currently, chronic fatigue syndrome (CFS) is considered as a special disease. This disease is accompanied by a set 
of symptoms that appear over a long time, usually more than six months. The most important symptom is unexpected and severe fatigue. The fatigue occurs even after low level mental/physical exertion, does not go away after sleep or rest, and is accompanied by various somatic manifestations [1-4].

In 1988, the Center for Disease Control (CDC, Atlanta, USA) identified CFS as an independent disease [10]. A new category was introduced in ICD-10 in 1992: postviral fatigue syndrome (G93.3). However, the question of the causes of CFS is still open. Several theories of the etiology of CFS are being developed: infectious, immune, toxic, psychogenic, and psychosocial ones [5-8].

The etiological factors of CFS are an unfavorable family/work environment (e.g., depression, anxiety, addiction), a negative psychological atmosphere during personality formation (e.g., violence, low self-esteem, and parental abuse), a sudden negative event (such as trauma, job loss, death of closely related person). Gender may also be a contributing factor: chronic fatigue syndrome develops more often among women. Triggering factors of CFS may be stress and viral infection. Moreover, it is stress that has been increasingly recognized as an important factor in the etiology and pathophysiology of CFS [9-10]

In addition, people with CFS often face scepticism and mistrust from close friends, family members, employers, government, community organizations and even health and social protection organizations. This leads to additional stress for the person, worsens the quality of one's life, and can also stimulate further development of the disease [11-12].

\subsection{Distance learning technologies as a potential factor of CFS among teachers}

At present, in the context of the urgent and widespread introduction of distance learning technologies, there is some inconsistency between the social role of the teacher and his or her real situation. On the one hand, the importance of pedagogical work increases, but on the other hand, its specificity, associated with certain difficulties in switching to a distance format, contributes to the emergence of stress and burnout among teachers, reduces their level of self-esteem and confidence in their own professional competence. These factors affect the health and working capacity of teachers, which may be temporarily lost [13-15].

The quality of education, especially distance education demands the knowledge and experience of teachers, as well as their capabilities in mastering new educational technologies. Therefore, the requirements for them are growing steadily.

The characteristics of professional activity in the field of education increase the likelihood of health problems for teachers. The widespread active introduction of distance learning technologies can contribute to the formation of emotional burnout, professional deformation, a state of pedagogical crisis, and a crisis of competence among teachers

The professional activity of teachers is often accompanied by problems with both physical and mental health that have been shown in empirical research. It was found that a significant part of teachers $(73 \%)$ tend to notice deterioration in mood, memory impairment, distraction, irascibility and impairment of all cognitive functions in general. A significant percentage $(91 \%)$ of teachers indicate the soreness of various organs and systems of the body, and only a small part (19\%) notes that they have a good well-being [16].

Additionally, A. K. Osnitsky showed that the likelihood of neurotic states among teachers increased in proportion to the length of their work experience. The level of social adaptation in a third of the surveyed teachers turned out to be lower than among patients with neurosis [17]. At the same time, a significant part of teachers was female, which made us think about the risk of developing CFS among them.

\section{RESEARCH AND METHODS}

The study was conducted in two stages: shortly before the introduction of distance learning in general education schools (in connection with the transition to self-isolation due to the COVID-19 pandemic) and after the introduction of distance learning.

Participants: 256 teachers (153 teachers before the introduction of the distance learning format, of which 115 women and 38 men, aged 20 to $65 ; 103$ teachers after the introduction of the distance learning format, including 74 women, 29 men, aged 20 to 65 years). Repeated measurements were carried out with the same respondents. The decrease in the sample was due to the refusal of a part of the respondents to take part in the study due to various circumstances (health status, change the place of stay, etc.)

The presence of chronic fatigue syndrome was assessed using The Fatigue Assessment Scale (FAS) (H. J. Michielsen, adapted by L. F. Bikbulatova) [18-19] and the questionnaire "Criteria for chronic fatigue syndrome" (S G. Komarov) [20]. Methods of mathematical statistics: The Pearson's chi-squared test and the Mann-Whitney U test. Statistical data processing was carried out using the SPSS-20.0 program.

\section{RESULTS AND DISCUSSION}

According to The Fatigue Assessment Scale (FAS), it was found that after the introduction of a distance learning format, $46.3 \%$ teachers of general education schools had pathological fatigue. Before the introduction of the distance format, only $17 \%$ teachers had symptoms of pathological fatigue, which is almost twice as rare.

According to self-assessment of the respondents using the model of the diagnostic algorithm of CFS by Komarov, no 
chronic fatigue syndrome was found in the samples of teachers before and after the introduction of the distance learning format. It was found that after the introduction of the distance learning format $3.8 \%$ of teachers had a low probability of developing CFS, and $35.8 \%$ had a risk of developing CFS. Before the introduction of the distance learning format, $3.8 \%$ of teachers had a low probability of developing CFS and $10.8 \%$ of respondents had a risk of developing CFS.

To determine the statistical significance by the degree of risk of developing chronic fatigue syndrome among teachers, we carried out a comparative analysis using Pearson's chi-squared test. The results showed that the risk of developing chronic fatigue syndrome among teachers was significantly higher after the introduction of a distance learning format than before it ( $p<0.0005)$.

Most often teachers had following symptoms: daytime sleepiness (51.9\%), headache (46.2\%), apathy and emotional depression (41.5\%), a general decrease in working capacity $(38.6 \%)$. Less often, teachers noted such symptoms as insomnia at night $(8.8 \%)$ and an increase of body temperature for a long time to $37-37.5^{\circ} \mathrm{C}(4.8 \%)$. In addition, after the introduction of the distance learning format, teachers twice more often noted that they had almost all symptoms, except daytime sleepiness and inflammation of the throat mucosa.

A comparative analysis carried out using the MannWhitney $U$ test revealed the existence of differences in the level of fatigue among teachers before and after the introduction of a distance learning format at a statistically significant level $(\mathrm{p}<0.001)$.

Thus, after the introduction of the distance learning format, teachers are more often worried about fatigue and the speed of its occurrence, lack of desire to do something, mental and physical exhaustion, lack of energy and low concentration. Comparison of the results of the study of the level of fatigue according to The Fatigue Assessment Scale (FAS) (H. J. Michielsen) and the risk of developing the syndrome according to the diagnostic model (S. G. Komarov) showed that as the risk of developing the syndrome increases, fatigue also increases, reaching a pathological level.

\section{CONCLUSION}

The introduction of a distance learning format in general education schools is a stressful factor for teachers.

After the introduction of the distance learning format, a significant part of the teachers was found to have pathological fatigue, as well as a high risk of developing chronic fatigue syndrome.

\section{REFERENCES}

[1] N.G. Artsimovich. Sindrom hronicheskoi ustalosti/ Artsimovich N.G., Galushkina T.S. - M.: Nauchnii mir, 2002.
[2] M. Barrow. Sindrom hronicheskoi ustalosti/ Maximilian Barrow [Perevod c angliiskogo E.K. Deniakinoi]. - M.: Izd. Dom "Panorama" Mejdunarodnii jurnal "Panorama”, 1999.

[3] L.M. Mitina, G.V. Mitin, O.A. Anisimova Professional`naia deiatelnost i zdorovie pedagoga. M.: Akademia. 2005

[4] N. Afari et al. Coping strategies in twins with chronic fatigue and chronic fatigue syndrome /Journal of psychosomatic research. 2000. T. 48.No. 6. C. pp.547-554.

[5] G.N. Gorokhovskaya. Sindrom hronicheskoi ustalosti/ G.N. Gorokhovskaya, E.V. Chernetsova, M.M. Petina, Yu.O. Zimaeva/ Vrach. 2009. № 12. P.88-90.

[6] S.G. Komarov. Sindrom hronicheskoi ustalosti: bolezn tsivilizatsii I indicator kachestva I bezopasnosti (okonchanie)/ S.G. Komarov, G.A. Georgii/ Standarti i kachestvo. 2009. No. 12. pp. 88-90.

[7] A.L. Komaroff. Chronic fatigue syndromes: relationship to chronic viral infections/ A.L. Komaroff/ J. Virol. Meth. 1988. Vol. 21. pp. 3 - 10.

[8] C. White, R. Schweitzer. The role of personality in the development and perpetuation of chronic fatigue syndrome /Journal of Psychosomatic Research. 2000. No. 6. pp. 515-524.

[9] S. Hempel et al. Risk factors for chronic fatigue syndrome/myalgic encephalomyelitis: a systematic scoping review of multiple predictor studies /Psychological medicine. 2008. No. 07. pp. 915-926.

[10] A. N. Mariman et al. Sleep in chronic fatigue syndrome /Sleep medicine reviews. 2013. T. 17. No. 3. pp. 193-199.

[11] U. M. Nater et al. Cumulative life stress in chronic fatigue syndrome /Psychiatry research. 2011. T. 189. No. 2. pp. 318-320.

[12] J. B. Prins et al. Social support and the persistence of complaints in chronic fatigue syndrome /Psychotherapy and psychosomatics. 2004. T. 73. No. 3. pp. 174-182.

[13] F.G. Aminev. Professional noe zdorovie uchitelia/Redaktsionnaia kollegia: DI Bahtizina. 2014. p.14.

[14] M.A. Kruglova, S.V. Myasnikova, L.A. Vereshagina, V.G. Kruglov, N.N. Lepekhin, O.V. 
Voronina. Job contex as a predictor of chronic fatigue syndrome in teachers / Astra Salvensis. 2018. T. 6. No. 1. C. pp. 687-697.

[15] M.A. Kruglova, E.S. Starchenkova, E.A. Stolyarchuk. Proactive coping with job burnout among teachers/ Science and Society №4, 2017; 12th International Scientific Conference «Science and Society» by SCIEURO in London, 24-29 November 2017, pp. 179-185.

[16] O.F. Jukov, N.S. Rossoshanskaya. Professional noe zdorovie uchitelia/ Uchenie zapiski universiteta im. P.F. Lesgafta. 2011. T. 73.No 3. pp. 124-131.

[17] A.K. Osnitsky. Reguliatornii opit, subiektnaia aktivnost i samostoiatel 'nost cheloveka. Chast 1 [Elektronnii resurs]/ Psihologicheskie issledovania: elektronnii nauchnii jurnal. 2009. No. 5(7). URL: http://psystudy.ru

[18] H.J. Michielsen. In search of personality and temperament predictors of chronic fatigue: a prospective study / Michielsen H.J., De Vries J., Van Heck G.L. // Personality and Individual Differences. 2003. - T. 35. - No.5. - pp. 1073-1087.

[19] L.F. Bikbulatova, M.A. Kutlubaev, L.R. Akhmadeeva. Shkala otsenki ustalosti: perevod na russkii iazik, adaptatcia i otcenka psihometriceskih svoistv v stacionarah klinik nevrologii i terapii/ Medicinskii vestnik Bashkortostana. 2012. No. 7. T.1. pp.37-42.

[20] S.G. Komarov. Sindrom hronicheskoi ustalosti (diagnostika i organizacia medicinskoi pomoshi). M.: MGMSU. 2007. 